\section{REFLEKSI HUKUM}

Jurnal Ilmu Hukum
p-ISSN 2541-4984 | e-ISSN 2541-5417

Volume 3 Nomor 2, April, Halaman 193-208

DOI: https://doi.org/10.24246/jrh.2019.v3.i2.p193-208

Open access at: http:// ejournal.uksw.edu/refleksihukum

Penerbit: Fakultas Hukum Universitas Kristen Satya Wacana

\title{
VERIFIKASI FAKTUAL PARPOL DALAM PERSPEKTIF JUSTICE AS FAIRNESS
}

\author{
Hery Wibowo Trisaksono \\ Lembaga Persemaian Cinta Kemanusiaan Salatiga \\ Korespondensi: herikadavidson@yahoo.com
}

\begin{abstract}
Abstrak
Isu hukum tulisan ini adalah apakah verifikasi faktual partai politik calon peserta pemilu 2019 kepada semua parpol seperti tertuang dalam Putusan Mahkamah Konstitusi Nomor 53/PUU-XV/2017, telah sesuai dengan prinsip keadilan?" Putusan Mahkamah Konstitusi tersebut bertujuan agar tercipta keadilan pemilu. Sehingga seluruh partai politik harus mengikuti verifikasi faktual partai politik yang diselenggarakan oleh Komisi Pemilihan Umum. Mahkamah Konstitusi mendasarkan pendapat konstitusionalnya pada Pasal 27 ayat (1) dan Pasal 28D ayat (3) Undang-Undang Dasar Negara Republik Indonesia Tahun 1945. Sebagai dasar putusan tentu keputusan tersebut sudah pada tempatnya, tetapi kurang substansial. Mahkamah Konstitusi memberikan pertimbangan hukum tentang keadilan hanya menggunakan 'prinsip persamaan', padahal dalam teori keadilan juga mengkaji mengenai 'prinsip perbedaan'. Sehingga Mahkamah Konstitusi perlu menambahkan alasan hukum dalam putusannya mengenai prinsip perbedaan dalam teori keadilan.
\end{abstract}

Kata Kunci: Mahkamah Konstitusi; Verifikasi Faktual; Parpol; Keadilan.

\begin{abstract}
The legal issue of this paper is whether factual verification of political parties in participating in the 2019 election for all political parties as stated in the Judgment of the Constitutional Court Number 53/PUU-XV/2017 is in accordance with the principle of justice or not. The Constitutional Court Judgment aims to create fairness of the election. Such effort aims to create an electoral justice by the obligation of undertaking the factual verification of political parties held by the General Elections Commission (Komisi Pemilihan Umum). The Constitutional Court laid its constitutional judgment on the interpretation of Article 27 (1) and Article 28D (3) of the 1945 Constitution of the Republic of Indonesia. The use of both Articles interpretation is correct but unfortunately less substantive. In its judgment, the Constitutional Court used legal reasoning based on the 'equality principle', whereas the 'difference principle' could also be considered in delivering the principle of justice. In conclusion, this paper urges the Constitutional Court to enrich its legal reasoning by applying the difference principle in the theory of justice.
\end{abstract}

Keywords: The Constitutional Court; Factual Verification; Political Party; Justice. 


\section{PENDAHULUAN}

Tulisan ini hendak mengkritisi pendapat yudisial Mahkamah Konstitusi Republik Indonesia (MKRI) dalam Putusan Nomor 53/PUU-XV/2017. Pendapat tersebut ditujukan terhadap isu konstitusionalitas ketentuan Pasal 173 ayat (1) dan ayat (3) UndangUndang Nomor 7 Tahun 2017 tentang Pemilihan Umum (UU Pemilu) terkait dengan verifikasi faktual partai politik (parpol) berdasarkan Pasal 27 ayat (1) dan Pasal 28D ayat (3) UndangUndang Dasar Negara Republik Indonesia Tahun 1945 (UUD 1945). Isu hukum yang akan didiskusikan adalah apakah pendapat yudisial MKRI dalam menjustifikasi verifikasi faktual semua parpol atas dasar keadilan telah sesuai dengan "prinsip keadilan yang seyogyanya". Pendapat yudisial MKRI yang hendak dikritisi tersebut secara spesifik menyatakan: "Keadilan Bagi Setiap Calon Peserta Pemilu, sebagaimana yang tercantum dalam Pasal 27 ayat (1) dan Pasal 28D ayat (3) UUD 1945."1 Pendapat ini menurut hemat penulis terlalu menggeneralisir situasi faktual yang sejatinya berbeda. Oleh karena itu, meskipun setuju dengan kesimpulan MKRI, namun penulis berpendapat bahwa perlu konsepsi keadilan yang berbeda dari yang dikemukakan oleh MKRI tersebut. Dengan demikian, penulis dalam posisi concurring opinion terhadap pendapat yudisial MKRI. ${ }^{2}$

Sebagai tanggapan atas pendapat yudisial MKRI tersebut, penulis mengusung konsepsi keadilan yang lebih substantif, sebagai lawan dari konsep keadilan formal yang menjadi poin dari pendapat yudisial MKRI. Keadilan yang lebih substantif di sini mempertanyakan hak parpol lama (parpol yang dalam pemilu sebelumnya telah duduk di kursi parlemen) yang berlindung di balik Pasal 173 ayat (1) dan ayat (3) UU Pemilu supaya tidak perlu menjalani verifikasi faktual sebagai bentuk privilise. Poin ini diabaikan oleh MKRI karena yang dimaknai sebagai keadilan oleh MKRI adalah semua parpol, lama atau baru, akan samasama menjadi peserta pemilu 2019. Tentu saja argumen demikian tidak sepenuhnya tepat, dalam kerangka konsep keadilan itu sendiri. Oleh karena itu, tesis penulis adalah meskipun parpol peserta pemilu 2019 datang dengan latar belakang berbeda (baca: partai baru versus partai lama peserta pemilu 2014 c.q. "partai senayan") tetapi perbedaan tersebut tidak memberikan hak kepada partai lama (privilise) peserta pemilu 2014 untuk mendapat perlakuan berbeda dalam pengaturan, yaitu tidak perlu menjalani verifikasi faktual.

MKRI hanya menginterpretasikan keadilan dalam arti persamaan saja,

\footnotetext{
Putusan Mahkamah Konstitusi Republik Indonesia Nomor 53/PUU-XV/2017, Mahkamah Konstitusi, 11 Januari 2018.

2 Imam Mahdi dalam Adam mengungkapkan bahwa concurring opinion, pada hakekatnya pendapat hukum (legal opinion), adalah pendapat tertulis dari beberapa hakim yang setuju terhadap kelompok mayoritas, tetapi tertulis dengan cara yang berbeda. Lihat, Haidar Adam, 'Dissenting Opinion dan Concurring Opinion dalam Putusan Mahkamah Konstitusi' (2017) 3 Al-Jinayah 308323. Sementara itu, menurut Faiz, concurring opinion atau penyampaian alasan atau pendapat berbeda dalam suatu putusan oleh hakim konstitusi telah menjadi praktek yang jamak yang dilakukan sejak permulaan Mahkamah Konstitusi berdiri. Lihat Pan Mohamad Faiz, 'Dari Concurring Hingga Dissenting Opinions: Menelusuri Jejak Pemikirian Hakim Konstitusi Maria Farida Indriati' (2018) dalam Pan Mohamad Faiz et.al., 'Serviam Pengabdian dan Pemikiran Hakim Konstitusi Maria Farida Indrati’ (Aura Publishing 2018) 4.
} 
padahal background keikutsertaan parpol dalam pemilu sangat berbeda. MKRI seharusnya tidak hanya mempertimbangkan persamaan dalam konteks semua parpol yang akan berkompetisi dalam pemilu 2019, tapi seyogyanya juga mempertimbangkan bahwa parpol yang akan berkompetisi dalam pemilu 2019 telah berkompetisi di pemilu 2014, dan telah mendudukkan wakil-wakilnya di Dewan Perwakilan Rakyat (DPR). Pertimbangan hukum tentang keadilan yang hanya menggunakan prinsip persamaan saja, menurut hemat penulis, itu kurang tepat. Seharusnya MKRI juga mempertimbangkan perbedaan tersebut dalam konteks keadilan dengan mengelaborasi konsepsi keadilan berdasarkan prinsip perbedaan. Atas dasar itu, tulisan ini hendak menjawab pertanyaan bagaimana seharusnya interpretasi yang tepat untuk Pasal 27 ayat (1) dan Pasal 28D ayat (3) UUD 1945 guna kemudian diterapkan sebagai dasar pengujian terhadap konstitusionalitas Pasal 173 ayat (1) sepanjang frasa "telah ditetapkan" dan ayat (3) UU Pemilu, yang dalam hal ini akan secara spesifik menggunakan 'teori keadilan' John Rawls.

Dengan demikian maka sistematika tulisan ini adalah sebagai berikut. Pertama, penulis akan mengelaborasi konsepsi keadilan berdasarkan teori keadilan yang dikembangkan oleh Rawls yang mempertimbangkan secara proporsional, dalam rangka keadilan, persamaan dan perbedaan perlakuan hukum. Hasil pembahasan ini akan diposisikan sebagai prinsip interpretif dalam memaknai Pasal 27 ayat (1) dan Pasal 28D ayat (3) UUD 1945. Kedua, atas dasar konsepsi tersebut penulis selanjutnya akan mengkritisi pendapat yudisial MKRI yang kurang tepat (dalam hal ini terlalu formal dan kurang substantif dalam memaknai Pasal 27 ayat (1) dan Pasal 28D ayat (3) UUD 1945 yang menjadi dasar pengujian dalam menentukan konstitusionalitas Pasal 173 ayat (1) dan ayat (3) UU Pemilu. Dengan posisi demikian maka dapat diberikan pendapat konstitusional yang lebih baik untuk isu konstitusionalitas Pasal 173 ayat (1) dan ayat (3) UU Pemilu.

\section{PEMBAHASAN}

\section{Persamaan dan Perbedaan Perlakuan Hukum dalam Perspektif Keadilan Rawls}

Fokus sub-judul ini adalah 'teori keadilan' yang dikemukakan oleh John Rawls. Pembahasan ini diposisikan sebagai prinsip interpretif terhadap Pasal 27 ayat (1) dan Pasal 28D ayat (3) UUD 1945 yang menjadi dasar pengujian dalam menentukan konstitusionalitas Pasal 173 ayat (1) dan ayat (3) UU Pemilu dalam Putusan MKRI No. 53/PUU-XV/2017. Poin utama dari Pasal 27 ayat (1) dan Pasal 28D ayat (3) UUD 1945 pada hakikatnya adalah tentang persamaan sebagai implementasi dari konsepsi keadilan. Oleh karena itu, untuk meletakkan prinsip interpretif terhadap Pasal 27 ayat (1) dan Pasal 28D ayat (3) UUD 1945, isu utamanya adalah bagaimanakah konsepsi keadilan yang lebih substantif dalam memaknai konsep persamaan tersebut. Jawaban atas pertanyaan tersebut adalah teori keadilan yang dikemukakan Rawls. ${ }^{3}$

3 Pan Mohamad Faiz, 'Teori Keadilan John Rawls' (2009) 6 Jurnal Konstitusi 135, 135. 
Mengapa perlu dikritisi dengan menggunakan pendapat Rawls? Salah satu poin pendapat yudisial MKRI terkait dengan verifikasi faktual kepada semua parpol adalah:

"Keadilan bagi setiap calon peserta pemilu". Perlakuan berbeda terhadap calon peserta Pemilu merupakan hal yang bertentangan dengan Konstitusi. Hal mana bukan saja karena hal itu bertentangan dengan hak untuk mendapat kesempatan yang sama dalam pemerintahan sebagaimana diatur dalam Pasal 27 ayat (1) dan Pasal 28D ayat (3) UUD 1945, melainkan juga karena perlakuan berbeda menjadi penyebab terjadinya ketidakadilan Pemilu. Merujuk salah satu indikator keadilan Pemilu adalah perlakuan yang sama atau setara antar peserta Pemilu. Baik perlakuan yang sama antar peserta Pemilu anggota DPR dan DPRD maupun antar seluruh peserta Pemilu yang ditentukan dalam UUD 1945....."4

Untuk mengkaji pendapat yudisial MKRI tersebut, penulis hendak menggunakan 'teori keadilan'. Keadilan adalah asas hukum yang universal dan identik dengan hukum, ${ }^{5}$ keadilan adalah kehendak yang teguh dan sinambung untuk memberikan kepada siapapun apa yang menjadi haknya. ${ }^{6}$ Keadilan merupakan salah satu tujuan hukum yang paling banyak dibicarakan sepanjang perjalanan filsafat hukum. ${ }^{7}$ Kendatipun keadilan bukan merupakan tujuan hukum satu-satunya akan tetapi tujuan hukum yang paling substantif adalah keadilan. ${ }^{8}$ Ada berbagai macam teori mengenai keadilan, salah satunya, teori keadilan sosial John Rawl, justice as fairness dalam bukunya a theory of justice. Menurut Koerniatmanto, sulit sekali memperoleh padanan kata dalam bahasa Indonesia bagi istilah justice as fairness. Barangkali istilah yang paling tepat adalah keadilan sebagai keadilan. Namun tentu saja ungkapan lndonesia ini tidak mengandung pesan apapun, bahkan tanpa makna. Atas dasar itu, maka istilah asli dalam bahasa lnggrislah yang akan dipergunakan dalam tulisan ini. ${ }^{9}$

Rawls dalam a theory of justice telah menjelaskan tentang keadilan, dalam hal ini justice as fairness ${ }^{10}$, sebagai the first virtues of social institutions yang menghasilkan gagasan tentang liberty and equality sebagai asas fundamental institusi sosial berdasarkan justice as fairness, ${ }^{11}$ yang ditandai dengan adanya prinsip

4 Putusan Mahkamah Konstitusi Republik Indonesia Nomor 53/PUU-XV/2017, Mahkamah Konstitusi, 11 Januari 2018, 113.

$5 \quad$ Krishna Djaya Darumurti, Diskresi Kajian Teori Hukum (Genta Publishing 2016) 68.

6 Ulpianus dalam Budiono Kusumohamidjojo, 'Ketertiban Yang Adil Versus Ketidakadilan: Beban Sosial-Ekonomi Yang Historis Dari Hukum’ (2016) 2 Veritas et Iustitia 1, 9.

Firman Freaddy Busroh, Teknik Perundang-Undangan Suatu Pengantar (Cintya Press 2016) 57. Ibid., 46.

Koerniatmanto Soetoprawiro, 'Keadilan sebagai Keadilan (Justice as Fairness)' (2010) 28 Pro Justitia 229, 230.

10 Menurut Sunaryo, sejak publikasi buku John Rawls, A Theory of Justice pada tahun 1971, gagasan mengenai keadilan telah menjadi tema penting dalam debat filsafat politik kontemporer. Buku itu merupakan perluasan dari artikel Justice as Fairness yang ditulis sebelumnya oleh Rawls pada 1957. Salah satu gagasan yang memantik pentingnya rumusan teori keadilan adalah dominasi pendekatan utilitarian dalam filsafat politik yang diinspirasi oleh Jeremy Bentham (1748-1832) dan Henry Sidgwick (1838-1900). Lihat: Sunaryo, 'Amartya Sen tentang Teori Keadilan John Rawls: Kritik Pendekatan Komparatif atas Pendekatan Institusionalisme' (2018) 23 Respons 11, 12.

11 Titon Slamet Kurnia, Mahkamah Konstitusi Republik Indonesia Sang Penjaga HAM (The Guardian of Human Rights) (PT. Alumni 2013) 103. 
rasionalitas, kebebasan dan kesamaan hak bagi setiap orang. ${ }^{12}$

Sebagai isu yang fundamental, keadilan menurut Rawls adalah cara bagi suatu institusi sosial dalam rangka mendistribusikan hak-hak dan kewajiban-kewajiban dasar internal serta untuk menentukan pembagian atas keuntungankeuntungan yang diperoleh melalui kerja sama sosial. Setelah diperoleh kesepakatan mengenai posisi keadilan di dalam suatu institusi sosial maka langkah selanjutnya adalah menentukan asas keadilan yang tepat secara fungsional sebagai dasar pengaturan bagi institusi sosial tersebut. Tentang kriterianya Rawls mendalilkan: "Everyone is presumed to act justly and to do his part in upholding just institutions". ${ }^{13}$

Rawls, seperti yang diuraikan oleh Hernoko'14, merumuskan dua prinsip keadilan (yang lebih mengutamakan asas hak), sebagai berikut:

a. Prinsip I, the greatest equal principle, bahwa setiap orang harus memiliki hak yang sama atas kebebasan dasar yang paling luas, seluas kebebasan yang sama bagi semua orang. Ini merupakan hal yang paling mendasar (hak asasi) yang harus dimiliki semua orang. Dengan kata lain, hanya dengan adanya jaminan kebebasan yang sama bagi semua orang maka keadilan akan terwujud (prinsip kesamaan hak); b. Prinsip II, ketidaksamaan sosial dan ekonomi harus diatur sedemikian rupa sehingga perlu diperhatikan asas atau prinsip berikut:

(1) the different principle, dan

(2) the principle of fair equality of opportunity.

First: each person is to have an equal right to the most extensive scheme of equal basic liberties compatible with a similar scheme of liberties for others.

Second: social and economic inequalities are to be arranged so that they are both (a) reasonably expected to be to everyone's advantage, and (b) attached to positions and offices open to all. ${ }^{15}$

Rawls mengklaim bahwa teori keadilannya merupakan alternatif dari utilitarianisme. ${ }^{16}$ Salah satu alasan yang dikemukakan oleh Rawls yaitu:

The primary reason for wanting to find such an alternative is the weakness, so I think, of utilitarian doctrine as a basis for the institutions of constitutional democracy. In particular, I do not believe that utilitarianism can provide a satisfactory account of the basic rights and liberties of citizens as free and equal persons, a requirement of absolutely first importance for an account of democratic institutions. I used a more general and abstract rendering of the idea of the social contract by means of the idea of the original position as a way to do that. A convincing account of basic rights and liberties, and of their priority, was the

12 Mariske Myeke Tampi, 'Analisis Teori Keadilan dalam Kontrak Kerja Konstruksi dan Aspek Penyelesaian Sengketanya' (2015) 9 Refleksi Hukum 65, 72.

13 Ibid.

14 Agus Yudha Hernoko, 'Keseimbangan Versus Keadilan Dalam Kontrak (Upaya Menata Struktur Hubungan Bisnis dalam Perspektif Kontrak yang Berkeadilan)' Pidato Pengukuhan Jabatan Guru Besar dalam Bidang Ilmu Hukum Kontrak pada Fakultas Hukum Universitas Airlangga di Surabaya pada hari Sabtu, tanggal 1 Mei 2010, Fakultas Hukum, Universitas Airlangga.

15 John Rawls, A Theory of Justice (The Belknap Press of Harvard University Press 1999) 53.

16 Krishna Djaya Darumurti, Op.Cit., 68. 
first objective of justice as fairness. A second objective was to integrate that account with an understanding of democratic equality, which led to the principle of fair equality of opportunity and the difference principle. ${ }^{17}$

Seperti tersurat dari pernyataan Rawls, utilitarianisme dianggap tidak mampu memberikan perlindungan memadai terhadap hak asasi manusia (HAM) yang merupakan tuntutan niscaya dari negara demokratis konstitusional. Karena lebih memberi prioritas perlindungan terhadap HAM, maka Rawls memperlakukan teori keadilannya sebagai alternatif bagi teori keadilan menurut pandangan utilitarianisme. ${ }^{18}$ Sebagai suatu teori yang oleh Ronald Dworkin disebut goal-based theory, utilitarianisme gagal untuk menjamin keadilan sosial karena lebih mendahulukan asas manfaat daripada asas hak. Karena kegagalan ini, maka utilitarianisme tidak tepat bila dijadikan basis untuk membangun suatu konsep keadilan. ${ }^{19}$

Rawls juga mengkritik intuisionisme karena tidak memberi tempat memadai pada asas rasionalistas. Instuisionisme dalam proses pengambilan keputusan (moral) lebih mengandalkan kemampuan intuisi manusia. Oleh karena itu, pandangan ini juga tidak memadai apabila dijadikan pegangan dalam mengambil keputusan, terutama pada waktu terjadi konflik di antara norma-norma moral. Dengan demikian, pertimbangan dan keputusan moral akan menjadi subyektif atau kehilangan obyektivitasnya. ${ }^{20}$
Belajar dari kegagalan teori-teori keadilan sebelumnya, Rawls merasa tertantang untuk membangun sebuah teori keadilan yang mampu menegakkan keadilan sosial dan sekaligus dapat dipertanggungjawabkan secara objektif. Tegasnya, Rawls ingin membangun sebuah konsep untuk membela keadilan, khususnya dalam perspektif demokrasi. Oleh karena itu, suatu teori keadilan yang memadai harus dibentuk dengan pendekatan kontrak di mana prinsip-prinsip keadilan yang dipilih sebagai pegangan bersama sungguh-sungguh merupakan hasil kesepakatan bersama dari semua orang yang bebas, rasional dan sederajat. Singkatnya, suatu teori keadilan yang memadai adalah teori yang mampu mengakomodasi sebuah kerjasama sosial yang pada saatnya akan mendukung terbentuknya suatu masyarakat yang tertib dan teratur. ${ }^{21}$

Rawls mengemukakan bahwa teori keadilannya ditujukan kepada,

"the basic structure of society, or more exactly, the way in which the major social institutions distribute fundamental rights and duties and determine the division of advantages from social cooperation. By major institutions I understand the political constitution and the principal economic and social arrangements. "22

Bagi Rawls, memperlakukan keadilan sebagai kebajikan pertama, berarti memberikan kesempatan secara adil dan sama bagi setiap orang untuk mengembangkan serta menikmati harga diri dan martabatnya sebagai manusia. Tinggi dan luhurnya

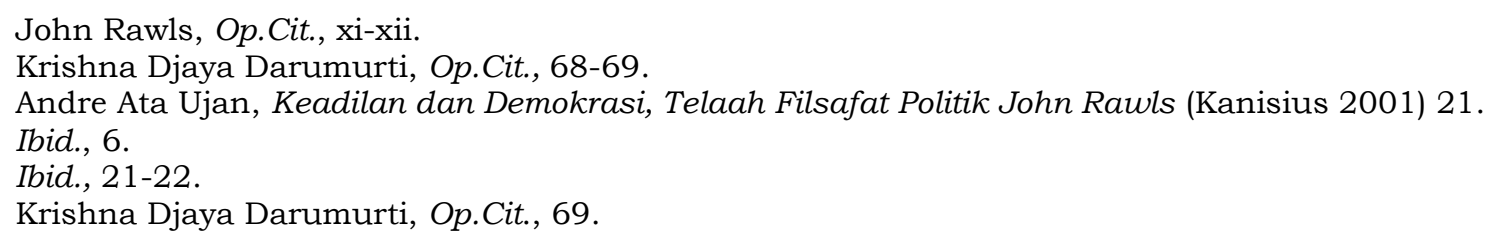


martabat manusia itu ditandai dengan kebebasan, karena itu kebebasan juga harus mendapat prioritas dibandingkan dengan keuntungan ekonomis yang bisa dicapai seseorang. ${ }^{23}$

Lebih lanjut, bagi Rawls suatu jaminan atas kebebasan yang sama bagi semua pihak justru merupakan jalan, khususnya bagi mereka yang kurang beruntung untuk berjuang meningkatkan hidupnya sebagai manusia. Dengan kata lain, keadilan sosial justru akan ditegakkan apabila setiap orang memiliki peluang dan kesempatan yang sama untuk menikmati pelbagai nilai-nilai atau manfaat sosial dasar yang tersedia di dalam masyarakat. Rawls percaya bahwa teori keadilan yang dikembangkannya merupakan teori yang sangat memadai karena konsep tersebut sepenuhnya mendukung asas fairness yang merupakan inti dari konsep keadilan. ${ }^{24}$

Bagi Rawls, keadilan harus dimengerti sebagai fairness, dalam arti bahwa tidak hanya mereka yang memiliki talenta dan kemampuan yang lebih baik saja yang berhak menikmati pelbagai manfaat sosial lebih banyak, tetapi keuntungan tersebut juga sekaligus harus membuka peluang bagi mereka yang kurang beruntung untuk meningkatkan prospek hidupnya. ${ }^{25}$ Terkait dengan hal tersebut, Rawls mengungkapkan:

"In justice as fairness one does not take men's propensities and inclinations as given, whatever they are, and then seek the best way to fulfill them. Rather, their desires and aspirations are restricted from the outset by the principles of justice which specify the boundaries that men's systems of ends must respect. We can express this by saying that in justice as fairness the concept of right is prior to that of the good. A just social system defines the scope within which individuals must develop their aims, and it provides a framework of rights and opportunities and the means of satisfaction within and by the use of which these ends may be equitably pursued." 26

Bahkan Rawls mengungkapkan bahwa setiap anggota masyarakat mempunyai hak yang sifatnya tidak bisa diganggu serta dilindungi oleh prinsip keadilan. Rawls mengatakan:

"Therefore in a just society the basic liberties are taken for granted and the rights secured by justice are not subject to political bargaining or to the calculus of social interests." 27

Teori keadilan Rawls memusatkan perhatian pada bagaimana mendistribusikan hak dan kewajiban secara berimbang di dalam masyarakat sehingga setiap orang berpeluang memperoleh manfaat darinya dan secara nyata menanggung beban yang sama. Demi menjamin distribusi yang fair serta mendorong kerja sama sosial itulah, maka menjadi penting bahwa prinsip pertama keadilan harus merupakan hasil dari suatu prosedur yang tidak memihak. Bagi Rawls, keadilan sebagai fairness adalah pure procedural justice. Itu berarti, keadilan sebagai fairness harus berproses dan sekaligus terefleksi melalui suatu prosedur yang adil. Oleh karena itu, kemungkinan penerimaan terhadap

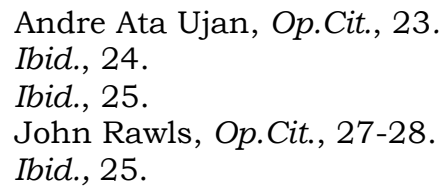


prinsip-prinsip pertama keadilan juga sangat tergantung pada penerimaan publik atas prosedur yang diterapkan dalam proses perumusan prinsipprinsip keadilan. ${ }^{28}$

Menurut Darumurti, pumpunan dari prinsip-prinsip keadilan dalam teori keadilan Rawls adalah posisinya yang lebih mengutamakan perlindungan hak ketimbang pertimbangan yang bersifat utilitarian. Artinya, teori keadilan Rawls tersebut berusaha memastikan supaya hak-hak individu tidak dikorbankan begitu saja demi kepentingan orang-orang yang lebih banyak. ${ }^{29}$ Sejalan dengan itu, di bagian lain tulisannya, Rawls menyatakan:

"Each person possesses an inviolability founded on justice that even the welfare of society as a whole cannot override. For this reason justice denies that the loss of freedom for some is made right by a greater good shared by others. It does not allow that the sacrifices imposed on a few are outweighed by the larger sum of advantages enjoyed by many. "30

Satu-satunya pengecualian yang dapat diterima dari situasi ini adalah untuk menghindari atau mencegah terjadinya ketidakadilan lebih besar:

"The only thing that permits us to acquiesce in an erroneous theory is the lack of a better one; analogously, an injustice is tolerable only when it is necessary to avoid an even greater injustice." 31

Rawls merumuskan dua prinsip keadilan yang diyakininya pasti dipilih oleh setiap orang yang berada dalam posisi asli, dan sekaligus menyingkir- kan prinsip keadilan yang ditawarkan oleh utilitarianisme. Sebagai orang, moral yang pada dasarnya rasional, bebas, dan setara semua pihak diyakininya akan memilih kedua prinsip keadilan yang diajukannya sebagai basis untuk ikatan kerja sama sosial yang saling menguntungkan. Dengan demikian, kedua prinsip keadilan Rawls dipilih karena secara esensial memiliki kemampuan untuk mengatur struktur sosial dasar sedemikian rupa sehingga mampu menjamin kepentingan, khususnya nilai-nilai primer, dari segenap anggota masyarakat. Dalam arti itu juga, kedua prinsip keadilan diharapkan mendukung suatu distribusi yang adil atas manfaat-manfaat serta nilainilai sosial (social goods), seperti pendapatan dan kekayaan, kebebasan dan kesempatan, serta harga diri. ${ }^{32}$ Teori keadilan sosial Rawls yang pada intinya terkristalisasi dalam dua rumusan keadilan yang disebutnya prinsip-prinsip pertama keadilan itu sesungguhnya bertolak dari suatu konsep keadilan yang lebih umum. ${ }^{33}$

"All social values liberty and opportunity, income and wealth, and the social bases of self-respect are to be distributed equally unless an unequal distribution of any, or all, of these values is to everyone's advantage". ${ }^{34}$

Ada dua hal penting yang patut dicatat sehubungan dengan konsep keadilan umum di atas. Pertama, kebebasan ditempatkan sejajar dengan nilai-nilai lainnya, dan dengan itu juga konsep umum keadilan ini tidak memberi tempat istimewa

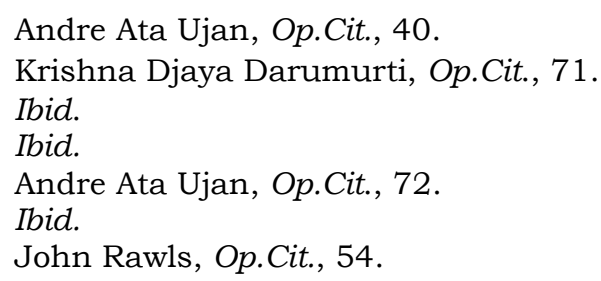


terhadap kebebasan. Hal ini pasti sangat berbeda dengan konsep keadilan Rawls yang berakar pada prinsip hak dan bukan pada prinsip manfaat sebagaimana sudah dijelaskan sebelumnya. Kedua, keadilan tidak selalu berarti semua orang harus selalu mendapatkan sesuatu dalam jumlah yang sama. Dengan kata lain, keadilan tidak selalu berarti semua orang harus dipelakukan secara sama tanpa memperhatikan perbedaanperbedaan penting yang secara obyektif ada pada setiap individu. Singkatnya, ketidaksamaan dalam distribusi nilai-nilai sosial selalu dapat dibenarkan, asalkan kebijakan itu ditempuh demi menjamin dan membawa manfaat bagi semua orang. Dengan demikian, Rawls memberi tempat serta menghargai hak setiap orang untuk menikmati suatu hidup yang layak sebagai manusia, termasuk mereka yang paling tidak beruntung (the worst off). ${ }^{35}$

Lebih lanjut, Rawls dalam Rasuanto mengungkapkan bahwa:

First Principle: Each person is to have an equal right to the most extensive total system of equal basic liberties compatible with a similar system of liberty for all. Second Principle: Social and economic inequalities are to be arranged so that they are both: (a) to the greatest benefit of the least advantaged, consistent with the just savings principle, and (b) attached to offices and positions open to all under conditions of fair equality of opportunity. ${ }^{36}$

Rumusan prinsip pertama kemudian diubah Rawls dengan menggantikan kata-kata the most extensive total system dengan a fully adequate scheme dan menyisipkan kata-kata which is antara liberties dan compatible. Sehingga rumusan prinsip pertama yang baru: Each person has an equal right to a fully adequate scheme of equal basic liberties which is compatible with a similar system of liberties for all. 37

Menurut Rawls, kekuatan dari keadilan dalam arti fairness justru terletak pada tuntutan bahwa ketidaksamaan dibenarkan sejauh juga memberikan keuntungan bagi semua pihak dan sekaligus memberi prioritas pada kebebasan. Ini merupakan dua tuntutan dasar yang dipenuhi dan dengan demikian juga membedakan secara tegas konsep keadilan sebagai fairness dari teoriteori yang dirumuskan dalam nafas intuisionisme dan dalam cakrawala teleologis. ${ }^{38}$

Dengan demikian, demi terjaminnya efektivitas dari kedua prinsip keadilan itu, Rawls menegaskan bahwa keduanya harus diatur dalam suatu tatanan yang disebutnya serial order atau lexical order.39 Dengan pengaturan seperti ini, Rawls menegaskan bahwa hak-hak serta kebebasan-kebebasan dasar tidak bisa ditukar dengan keuntungankeuntungan sosial dan ekonomis. Itu berarti, prinsip keadilan yang kedua hanya bisa mendapat tempat dan diterapkan apabila prinsip keadilan pertama telah terpenuhi. Dengan kata lain, penerapan dan pelaksanaan prinsip keadilan yang kedua tidak

\footnotetext{
35 Andre Ata Ujan, Op.Cit., 72-73.

36 Bur Rasuanto, 2005, Keadilan Sosial Pandangan Deontologis Rawls dan Habermas, Dua Teori Filsafat Politik Modern (Gramedia Pustaka Utama 2005) 47.

Ibid.

Andre Ata Ujan, Op.Cit., 73.

Ibid.
} 
boleh bertentangan dengan prinsip keadilan yang pertama. Oleh karena itu, hak-hak dan kebebasan-kebebasan dasar dalam konsep keadilan khusus ini memiliki prioritas utama atas keuntungan-keuntungan sosial dan ekonomis. 40

Tuntutan Rawls untuk memberikan prioritas kepada hak dan kebebasan dasar memperlihatkan bahwa sesungguhnya ada banyak nilai dasar (basic goods), yakni nilai-nilai yang diperlukan untuk kelayakan hidup sebagai manusia dan karenanya harus dilindungi. Namun, tidak semua nilai dasar berada pada tingkat yang sama. Dengan kata lain, ada perbedaan gradual dalam skala prioritas diantara nilai-nilai dasar itu. Oleh karena itu, hak dan kebebasan dasar serta keuntungan sosial dan ekonomis pasti merupakan nilai-nilai yang sangat penting bagi manusia dan karenanya sama-sama disebut sebagai basic goods. Akan tetapi, kebebasan sebagai nilai menempati urutan lebih tinggi dibandingkan dengan keuntungan atau kepentingan sosial dan ekonomis. Kutipan berikut memperlihatkan dengan jelas sikap dasar Rawls tersebut. ${ }^{41}$

"The first principle simply requires that certain sorts of rules, those defining basic liberties, apply to everyone equally and that they allow the most extensive liberty compatible with a like liberty for all. The only reason for circumscribing basic liberties and making them less extensive is that otherwise they would interfere with one another". ${ }^{42}$

Ibid.

Ibid., 73-74.

John Rawls, Op.Cit., 56.

Andre Ata Ujan, Op.Cit., 74.

Bur Rasuanto, Op.Cit., 81.
Prinsip keadilan yang kedua menuntut bahwa ketidaksamaan dalam pencapian nilai-nilai sosial dan ekonomi diperbolehkan apabila tetap membuka peluang bagi pihak lain untuk mendapatkan manfaat dalam hal yang sama. Oleh karena itu, ketidaksamaan dalam perolehan nilai sosial dan ekonomi tidak harus selalu dimengerti sebagai ketidakadilan. Inti dari prinsip keadilan yang kedua justru terletak pada sisi ini. Meskipun demikian, prinsip yang kedua ini bisa mengundang banyak interpretasi yang berbeda dengan akibat bahwa pengaturan struktur sosial pun akan berbeda-beda pula. Oleh karena itu, penting untuk melihat pelbagai interpretasi berbeda atas prinsip keadilan yang kedua ini yang pada akhirnya menunjukkan interpretasiinterpretasi yang tepat dari sudut keadilan sebagai fairness. ${ }^{43}$

Prinsip perbedaan tidak menghapuskan ketaksamaan, melainkan membuat ketaksamaan ekonomi dan sosial, maupun kelebihan alami dan bakat menguntungkan semua, terutama mereka yang kurang beruntung. Prinsip perbedaan dengan demikian bukan hanya memberi arti ideal prinsip kesamaan kesempatan fair paham liberal, tapi juga "mentransformasikan secara fundamental tujuantujuan masyarakat." 44 Atau seperti komentar dengan nada memuji dari salah seorang komunitarian pengritik utama Rawls, Michael Sandel. Ungkapan pujian itu di antaranya:

"The difference principle is not simply a fuller version of the principle of fair opportunity; it attacks the problem of 
arbitrarines in a fundamentally different way. Rather than transform the con 1 tions under which I exercise my talents, the difference principe transforms the moral basis on which I claim the benefits that ow from them." 45 (Prinsip perbedaan bukan sekadar suatu versi paling lengkap prinsip kesamaan kesempatan; prinsip itu menyerang problem kebetulan atau arbitrer dengan jalan yang secara fundamental berbeda. Alih-alih mentransformasikan kondisi-kondisi di bawah mana saya menerapkan bakat-bakat saya, prinsip perbedaan mentrasformasikan basis moral terhadap mana saya mengklaim nikmat-nikmat yang mengalir dari bakat-bakat saya itu. ${ }^{46}$

Kritik Sandel atas Rawls atas ketidaksepakatannya dengan pengandaian antropologis John Rawls yang cenderung individualistik dan mencabut manusia dari pengaruh komunitasnya. Jadi, konsepsi keadilan Rawls masihlah didasarkan pada pandangan metafisis tentang siapa atau apa itu manusia. ${ }^{47}$

\section{Kritik Substantif Terhadap Pendapat Yudisial MKRI Berdasarkan Teori Keadilan Rawls}

Di bagian awal tulisan ini penulis telah menyatakan bahwa isu hukum tulisan ini ditujukan untuk mengkritisi pendapat yudisial MKRI dalam melakukan interpretasi terhadap Pasal 27 ayat (1) dan Pasal 28D ayat (3) UUD 1945 ketika menguji konstitusionalitas Pasal 173 ayat (1) dan ayat (3) UU Pemilu. Kritik ini hanya akan ditujukan pada poin pendapat yudisial MKRI yang menekankan konsep keadilan sebagai persamaan dalam pengertian "Keadilan bagi setiap calon peserta pemilu." Pendapat MKRI tersebut dapat dikategorikan sebagai pendapat formal karena MKRI hanya melihat bahwa partai-partai tersebut merupakan partai-partai calon peserta pemilu 2019. Padahal kondisinya berbeda, karena ada parpol yang telah berkompetisi dalam pemilu 2014 dan ada parpol yang baru akan ikut berkompetisi dalam pemilu 2019. Pendapat itu kurang memuaskan dalam menjustifikasi inkonstitusionalitas Pasal 173 ayat (1) dan Pasal 173 ayat (3) UU Pemilu. Oleh karena itu, meski setuju dengan kesimpulan bahwa pasal tersebut inkonstitusional, tetapi penulis akan mengemukakan argumen substantif yang lebih memuaskan dari pendapat MKRI di atas.

Parpol yang berkompetisi dalam pemilu 2014 dan turut andil dalam pengesahan UU Pemilu telah memiliki dukungan dari rakyat, salah satunya dengan memiliki kursi di DPR ("partai senayan"). Sebaliknya ada pula parpol yang baru akan turut berkompetisi dalam pemilu 2019 ("parpol baru”). Sehingga kondisi untuk berkompetisi dalam pemilu 2019 sangatlah berbeda. Oleh karena itu, pertanyaannya apakah "partai senayan" berhak untuk dibedakan dari "partai baru" terkait dengan pengecualian verifikasi faktual parpol peserta pemilu 2019 ?

Menurut hemat penulis, "parpol senayan" tidak berhak dibedakan dengan "parpol baru" karena "parpol senayan" telah mengikuti kompetisi di pemilu sebelumnya. Sehingga "parpol senayan" lebih memiliki kesempatan

\footnotetext{
45 Michael J. Sandel, Liberalism and the Limits of Justice (Cambridge University Press 1992) 70.

46 Bur Rasuanto, Op.Cit., 81.

47 Reza Antonius A.W., 'Richard Rorty dan Ruang Publik Para "Penyair"?: Sebuah Tematisasi Konsep Ruang Publik di Dalam Filsafat Politik Richard Rorty’ (2008) 24 Melintas 57, 62.
} 
untuk menjadi peserta pemilu di pemilu berikutnya. Selain itu, "parpol senayan" telah memiliki sumber daya yang dibutuhkan agar bisa turut serta dalam pemilu 2019. Sumber daya tersebut antara lain, terpenuhinya legalitas sebagai parpol dan telah mendudukkan kader-kadernya sebagai anggota legislatif. Terlebih lagi, "parpol senayan" juga telah memiliki kepengurusan sampai ke desa-desa.

Dworkin dalam Marzuki mengemukakan, "rights are best understood as trumps over some background justification for political decisions that the states a goal for the community as a whole". 48 Lebih lanjut, Dworkin menyatakan bukan hak yang diciptakan oleh hukum, melainkan hak yang memaksa adanya hukum. ${ }^{49}$ Terkait dengan hak, dalam justice as fairness, Rawls mengungkapkan "each person has an equal right to a fully adequate scheme of equal basic liberties which is compatible with a similar scheme of liberties for all."50

Oleh Rawls, asas hak tersebut dijustifikasi dengan kekuatan moral yaitu:

First, the capacity for a sense of justice, exercised in deliberating with others about the form of shared social institution, and second, the capacity for a conception of the good, exercised in deliberating about how to live one's own life. ${ }^{51}$

Kedua argumen tersebut tampak menonjol dalam penguatan tradisi hak. Bila dikaitkan dengan argumen tersebut, "partai senayan" tidak memiliki alas hak untuk membuat UU, terkait dengan verifikasi faktual parpol peserta pemilu 2019, yang menguntungkan dan bermuara mengecualikan mereka dari proses verifikasi faktual parpol peserta pemilu 2019. Selain itu, "parpol senayan" juga telah melakukan tindakan "tidak bermoral" karena tanpa alas hak telah membuat UU yang menguntungkan mereka dengan membebankan beban yang lebih berat (verifikasi faktual parpol peserta pemilu 2019) kepada pihak lain ("partai baru").

Terlebih lagi, pengaturan mengenai verifikasi faktual parpol peserta pemilu telah pernah diatur dalam Pasal 8 ayat (1) UU No. 8 Tahun 2012 tentang Pemilihan Umum Anggota Dewan Perwakilan Rakyat, Dewan Perwakilan Daerah, dan Dewan Perwakilan Rakyat Daerah yang menyatakan bahwa parpol peserta pemilu pada pemilu terakhir yang memenuhi ambang batas perolehan suara dari jumlah suara sah secara nasional ditetapkan sebagai parpol peserta pemilu pada pemilu berikutnya, dan oleh MKRI, pengaturan itu dianggap inkonstitusional terhadap UUD 1945 melalui Putusan MKRI No. 52/PUU-X/2012. Meski DPR memiliki kewenangan open legal policy untuk membuat UU, tapi tindakan "partai senayan" dengan menghidupkan kembali norma yang bertentangan dengan UUD 1945 merupakan tindakan yang tidak memiliki alas hak dan alas moral.

Ihwal dihidupkannya kembali norma yang telah pernah dinyatakan inkonstitusional oleh MKRI, telah ditegaskan MKRI dalam Putusan No. 105/PUU-XIV/2016, bertanggal 28

\footnotetext{
48 Peter Mahmud Marzuki, Pengantar Ilmu Hukum (Kencana Prenada Media Group 2008) 178. Lihat juga dalam Darlei Dall'Agnol, 'Dworkin's Liberal Egalitarianism' (2006) 2 Kriterion 1, 4.

Ibid., 180.

John Rawls, Political Liberalism (Columbia University Press 1996) 291.

Ibid., 332-333.
} 
September 2017, yang menyatakan antara lain:

"Sebagai institusi yang diberikan wewenang konstitusional oleh konstitusi untuk menguji UU terhadap UUD 1945 langkah yang paling mungkin dilakukan Mahkamah merespon dan sekaligus mengantisipasi segala macam pengabaian terhadap normanorma atau bagian-bagian tertentu suatu UU yang telah dinyatakan bertentangan dengan UUD 1945 tetapi dihidupkan kembali dalam revisi UU atau dalam UU yang baru, maka bagi Mahkamah hal demikian akan menjadi bukti yang tidak terbantahkan untuk menyatakan norma UU yang bersangkutan bertentangan dengan UUD 1945". 52

Berdasarkan argumen-argumen di atas, bila dikaitkan dengan prinsip keadilan Rawls (justice as fairness) khususnya mengenai prinsip perbedaan (the difference principle), Rawls menyatakan, "they are to be to the greatest benefit of the least advantaged members of society" 53, maka "parpol senayan" bukan merupakan (kelompok) masyarakat yang 'disadvantage'/ 'vulnerable' karena mereka telah memiliki pengalaman di pemilu 2014 dan telah mendudukkan anggotanya menjadi legislator. Sehingga sudah selayaknyalah apabila "parpol senayan" tidak masuk kualifikasi untuk diperlakukan secara berbeda dengan "parpol baru". Oleh karena itu, sepatutnyalah apabila "parpol senayan" juga harus mengikuti verifikasi faktual parpol dan tidak layak berlindung di sebalik prinsip perbedaan.

\section{PENUTUP}

Berdasarkan argumentasi yang telah dikemukakan di atas, maka dapat disimpulkan bahwa putusan MKRI No. 53/PUU-XV/2017 yang menyatakan Pasal 173 ayat (1) dan Pasal 173 ayat (3) UU Pemilu inkonstitusional terhadap UUD 1945 telah tepat karena sesuai dengan prinsip keadilan dalam pemilu. Sehingga seluruh parpol calon peserta pemilu 2019 selayaknyalah mengikuti proses verifikasi administrasi dan verifikasi faktual yang akan dilakukan oleh Komisi Pemilihan Umum. Pertimbangan MKRI tentang pemberlakuan syarat yang sama kepada seluruh parpol merupakan perlakuan yang sama untuk duduk dalam pemerintahan, yang sesuai dengan Pasal 27 ayat (1) dan Pasal 28D ayat (2) dan (3) UUD 1945.

Keadilan bagi setiap calon peserta pemilu harus dimaknai sebagai "treat like cases alike and different cases differently"54. Sehingga argumentasi keadilan tidak hanya menggunakan prinsip persamaan saja, tetapi juga prinsip perbedaan. Keadilan yang sejalan dengan isu verifikasi faktual parpol adalah justice as fairness (keadilan Rawlsian). Suatu teori keadilan yang menggunakan kerangka pikir kontrak sosial yaitu prinsipprinsip keadilan yang disetujui atau disepakati dalam situasi yang fair dan lebih mengutamakan perlindungan hak.

Pertimbangan MKRI mengenai keadilan menggunakan argumentasi

\footnotetext{
52 Putusan Mahkamah Konstitusi Republik Indonesia Nomor 53/PUU-XV/2017, Mahkamah Konstitusi, 11 Januari 2018, 119.

53 John Rawls, Op.Cit., 5-6.

54 Pembahasan lebih dalam mengenai hal tersebut bisa diekplorasi dalam The Concept of Law karya H.L.A. Hart. Namun demikian, untuk mempermudah pembahasannya bisa dilihat dalam Kenneth I. Winston, 'On Treating Like Cases Alike' (1974) 62 California Law Review 1-39.
} 
formal karena masih menyamaratakan seluruh parpol peserta pemilu 2019 untuk diverifikasi faktual. Padahal prakondisinya sangat berbeda. Ada parpol yang telah mendudukkan anggotanya di DPR dan ada parpol yang baru akan berkompetisi dalam pemilu 2019. Sehingga, meski kesimpulannya sama (seluruh parpol harus diverifikasi faktual), tapi MKRI selayaknya juga membangun argumentasi bahwa "parpol senayan" tidak punya hak untuk dibedakan (dikecualikan dari verifikasi faktual parpol) dengan "parpol baru". Ini sesuai dengan pendapat Rawls mengenai prinsip perbedaan bahwa "parpol senayan" tidak punya hak untuk dibedakan karena mereka bukan kelompok yang "disadvantage/ vulnerable".

\section{DAFTAR BACAAN}

\section{Buku}

Busroh, Firman F., Teknik PerundangUndangan Suatu Pengantar (Cintya Press 2016).

Darumurti, Krishna D., Diskresi Kajian Teori Hukum (Genta Publishing 2016).

Faiz, Pan M., (et.al), 'Serviam' Pengabdian dan Pemikiran Hakim Konstitusi Maria Farida Indrati' (Aura Publishing 2018).

Kurnia, Titon S., Mahkamah Konstitusi Republik Indonesia Sang Penjaga HAM (The Guardian of Human Rights) (Alumni 2013).

Marzuki, Peter M., Pengantar Ilmu Hukum (Kencana Prenada Media Group 2008).

Rasuanto, B., Keadilan Sosial Pandangan Deontologis Rawls dan Habermas, Dua Teori Filsafat
Politik Modern (Gramedia Pustaka Utama 2005).

Rawls, J., A Theory of Justice (The Belknap Press of Harvard University Press 1999).

Rawls, J., Political Liberalism (Columbia University Press 1996).

Sandel, Michael J., Liberalism and The Limits of Justice (Cambridge University Press 1992).

Ujan, Andre A., Keadilan dan Demokrasi, Telaah Filsafat Politik John Rawls (Penerbit Kanisius 2001).

\section{Artikel Jurnal}

Adam, H., 'Dissenting Opinion dan Concurring Opinion Dalam Putusan Mahkamah Konstitusi' (2017) 3 Al-Jinayah.

Dall'Agnol, D., 'Dworkin's Liberal Egalitarianism' (2006) 2 Kriterion.

Faiz, Pan M., 'Teori Keadilan John Rawls' (2009) 6 Jurnal Konstitusi.

Kusumohamidjojo, B., 'Ketertiban Yang Adil Versus Ketidakadilan: Beban Sosial-Ekonomi Yang Historis Dari Hukum' (2016) 1 Veritas et Iustitia.

Soetoprawiro, K., 'Keadilan sebagai Keadilan (Justice as Fairness)' (2010) 28 Pro Justitia.

Sunaryo, 'Amartya Sen tentang Teori Keadilan John Rawls: Kritik Pendekatan Komparatif atas Pendekatan Institusionalisme' (2018) 23 Respons.

Tampi, Mariske M., 'Analisis Teori Keadilan dalam Kontrak Kerja Konstruksi dan Aspek Penyelesaian Sengketanya' (2015) 9 Refleksi Hukum. 
W., Reza Antonius A., 'Richard Rorty dan Ruang Publik Para "Penyair"?: Sebuah Tematisasi Konsep Ruang Publik di Dalam Filsafat Politik Richard Rorty' (2008) 24 Melintas.

Winston, Kenneth I., 'On Treating Like Cases Alike' (1974) 62 California Law Review.

\section{Putusan Pengadilan}

Putusan Mahkamah Konstitusi Republik Indonesia Nomor 52/PUU-X/2012, Mahkamah Konstitusi, 15 Agustus 2012.

Putusan Mahkamah Konstitusi Republik Indonesia Nomor 53/PUU- XV/2017, Mahkamah Konstitusi, 11 Januari 2018.

\section{Peraturan Perundang-Undangan}

Undang-Undang Dasar Negara Republik Indonesia 1945.

Undang-Undang Nomor 8 Tahun 2012 tentang Pemilihan Umum Anggota Dewan Perwakilan Rakyat, DewanPerwakilan Daerah, dan Dewan Perwakilan Rakyat Daerah.

Undang-Undang Nomor 7 Tahun 2017 tentang Pemilihan Umum.

\section{Lain-lain}

Hernoko, Agus Yudha, 'Keseimbangan Versus Keadilan Dalam Kontrak (Upaya Menata Struktur Hubungan Bisnis dalam Perspektif Kontrak yang Berkeadilan)', Pidato Pengukuhan Jabatan Guru Besar dalam Bidang Ilmu Hukum Kontrak pada Fakultas Hukum Universitas Airlangga di Surabaya pada Hari Sabtu, Tanggal 1 Mei 2010, Fakultas Hukum, Universitas Airlangga. 
